\title{
DRIVING FORCES, THREATS AND TRENDS RELATING TO MOSAICS IN AGRICULTURAL LANDSCAPE IN SLOVAKIA
}

\author{
JANA SPulerova, Marta Dobrovodská, Dagmar StefunKova
}

Institute of Landscape Ecology, Slovak Academy of Sciences, Stefanikova 3, 81499

Bratislava, Slovakia, email: jana.spulerova@savba.sk, marta.dobrovodska@savba.sk, dagmar.stefunkova@savba.sk

Received: $27^{\text {th }}$ November 2009 , Accepted: $9^{\text {th }}$ November 2010

\begin{abstract}
The present cultural landscape is a result of development which has been carried out for several thousand years. The land - use changes, driving forces, threats and trends relating to agricultural landscape mosaics in Slovakia were studied using examples of model areas with preserved landscape mosaics: the villages Zuberec - Habovka, Liptovská Teplička, Osturňa and the town of Svätý Jur.

The primary land cover of the Slovak republic was mostly forest. The outstanding feature of the landscape, as a result of settlement, deforestation and colonisation, was a landscape characterised by a high biodiversity and cultural mosaic because of the heterogeneity of land forms and cover, relief segmentation, and a variety of farming products. The most important interventions in the landscape started in the second half of the $20^{\text {th }}$ century. Intensification of agriculture was linked with collectivisation and removal of hedges and riparian vegetation, decreasing the mosaic of arable fields, grasslands and woods. Landscape mosaics were transformed into large fields. Only in less accessible, less fertile localities was the original agricultural landscape partially preserved, and did not lose the shape of a cultural-historical countryside. At the same time, partial abandonment and reforestation has started as a consequence of changes in employment patterns and the decline of populations.

After 1990 the landscape was partly retrospectively diversified by virtue of land restitution. Although the decline of the traditional use of farmland is noticeable in Slovakia, in some regions local inhabitants are strongly linked to traditional land use. In less accessible, less fertile localities, abandonment of traditional agriculture and succession dominance of forest continues. The challenge to maintain the original agrarian landscape could be supported by agro-environmental schemes. However, localities with beneficial geographical positions are threatened. The town of Svätý Jur faces non-regulated urbanisation, old vineyards are being replaced by new villas and houses for recreation. The villages of Zuberec - Habovka face non regulated tourism. The marginal sites, Osturňa, Liptovská Teplička are threatened by abandonment and the subsequent overgrowth by woody vegetation.
\end{abstract}

Keywords: historical agricultural landscape, DPSIR, developmental trends 


\section{INTRODUCTION}

The cultural landscape considers different aspects of man's intervention with natural vegetation and landscape resulting from a long equilibrium of co-existence. The present cultural landscape is a result of development which has been carried out for several thousand years. Transformation of landscapes is considered to be one of the main driving forces behind species loss both, regionally and globally (Lindborg and Eriksson 2004). More recently, Man, through his activities, has radically transformed the landscape by clearing forests, cultivating land and building settlements. These landscapes are not stable, and the recent and ever accelerating changes in technology and life-style have increasingly affected many ancient landscapes, as old land-use practices have been abandoned and traditions forgotten (Birks et al. 2004). Although historical human activities are generally acknowledged as being important for biodiversity patterns, few studies have estimated the relative importance of past and present conditions (Bruun et al. 2001, Cousins and Eriksson 2002). The revolutionary changes in landscape mosaic (microstructure) in the past 40 years have had a particularly decisive influence on landscape stability and landscape structure, expressed in land use and spatial arrangement, playing the main role in landscape dynamics (Lipský 1995). Original and preserved agricultural landscape, where human activities through history consciously transformed the environment, can be described as historical landscape structure (Huba et al. 1988; Dobrovodská and Štefunková 1996). Historical agricultural landscape is a type of cultural landscape that contains, within a geographic area, both, natural and manmade features that typify connected activities, past events or patterns of physical development (Antrop 2005). The regional differences of the historical landscape structure such as their material content, shape, texture, morphology, colouring, location in the landscape or scale division are strongly influenced or determined by the natural condition, or the geographical, cultural or economic location of the area in individual historical periods.

The main object of the research was to study land use changes of agricultural landscapes in Slovakia and to define the main driving forces, threats and trends impacting preservation of the traditional agricultural mosaic. By studying the land use changes, it is possible to perceive the human impact on the environment in terms of history, as well as the evolution of human intellect, their working tools, materials and equipment (Dobrovodská 1998).

The article describes and traces the development of agricultural landscapes in different cultural and bio-geographical regions in Slovakia. Remaining residua of mosaics in agricultural landscape were described in different parts of Slovakia, where traditions have lingered because the rugged topography of the region is adverse to high-technology.

\section{METHODS}

The research was focused on identification of driving forces, the present state of mosaics, and threats to the mosaic in the agricultural landscape in Slovakia using examples of the selected representative settlements - the town of Sväty Jur, the village of Liptovská Teplička, the villages Zuberec - Habovka, and the village of Osturn̆a (Figure 1). The methodological approach is partially built around a conceptual framework known as the DPSIR assessment framework (GIWA 2001) and LANDEP methodology (Ružička and Miklós 1982). DPSIR stands for Driving forces, Pressures, States, Impacts and Responses. The LANDEP consists of analyses, syntheses and interpretations of natural and socioeconomic conditions, evaluations and propositions aimed at optimal land use. 
As driving forces we considered socio-economic forces and natural conditions, which are driving human activities to utilize landscape in a specific way. Applying the methodological approaches of LANDEP identification of the main driving forces was based on analyses, syntheses and their interpretations of historical and current socio-politiceconomic conditions and natural conditions (Dobrovodská 2003; Štefunková and Dobrovodská 1997; Špulerová 2008a). The contemporary result of the impact of driving forces in time and space are various types of agricultural land-use which create the present state of the cultural mosaics in the agrarian landscape.

The main threats for the agricultural mosaics were determined on the basis of the comparison of conflicts between the present state of the mosaics and the main potential and real driving forces.

The trends are dependent on the realization or non-realization of threats. They are the responses of the landscape to the pressure of human activities. They can tend to the two main states of the agricultural mosaic - the developmental trend of the mosaic (optimal land-use) when the threats were minimized or the disintegration trend of the mosaic (gradual extinction of mosaic) when the threats were transformed into real activities pressures on the mosaic.

Fig. 1: Localization of the model areas in Slovakia

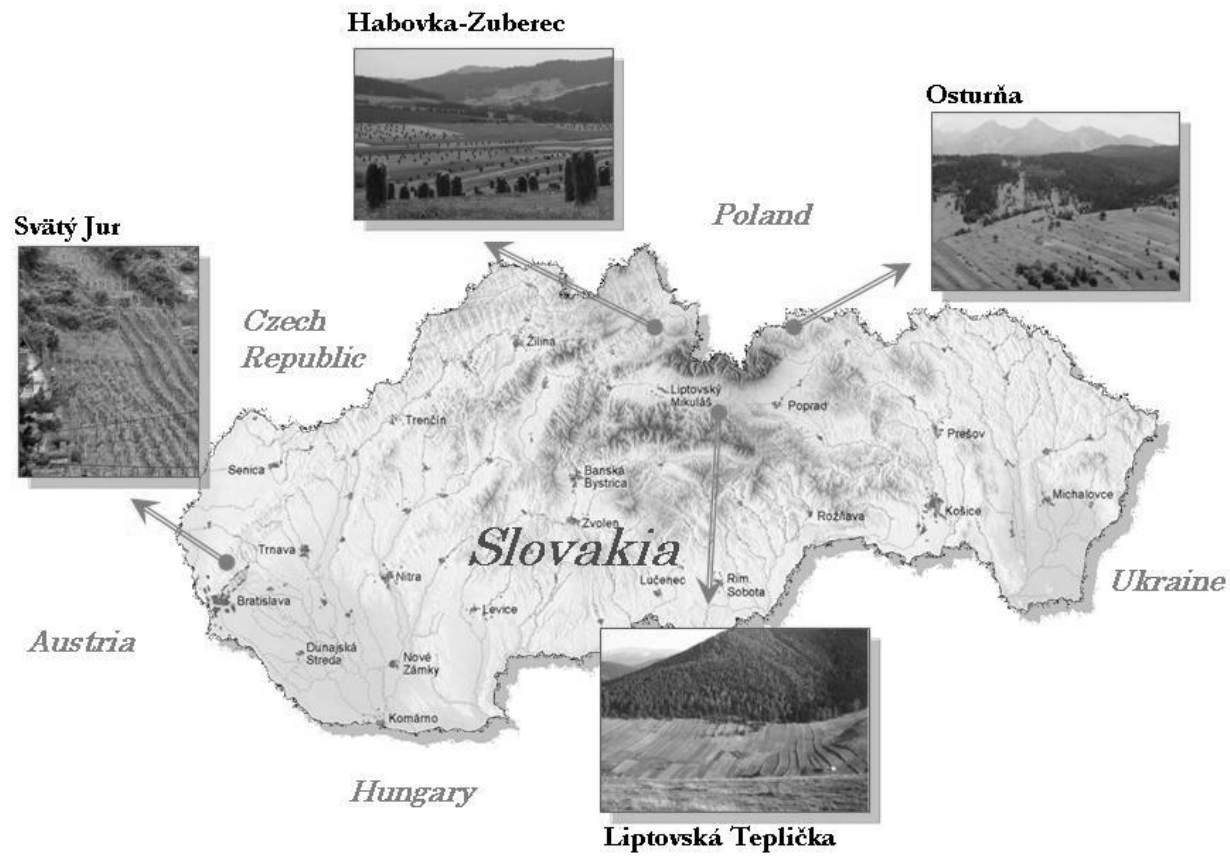

\section{RESULTS}

\section{Agricultural land-use changes in Slovakia}

The present landscape is the result of several development factors - agriculture, urbanisation, transportation requirements, economy etc. Man and his activities have become 
the most important and dynamic landscape factors. Results of these activities are changes in the aspect, structure and functions of landscape. The primary land cover of the Slovak republic was mostly forest. The Slavic population settled in the territory of Slovakia in the $5^{\text {th }}$ century. The agricultural development and agricultural land area in the Slovak territory were significantly supported by several stages of colonization of domestic and foreign origination. Farm colonization, was partly carried out by the German population, until the Wallachian colonization, which caused massive forest reduction in favour of meadows and pastures in the mountain areas. The outstanding feature of the landscape, as a result of settlement, deforestation and colonisation, was a landscape characterised by high biodiversity and cultural mosaics, because of the heterogeneity of land forms and cover, relief segmentation, and the variety of farming products. Further revival and extension of cultivated areas took place in the $2^{\text {nd }}$ half of the 19 th century.

\section{Collectivisation and intensification of agriculture (1950-1990)}

The most important interventions in the landscape started in the second half of the $20^{\text {th }}$ century. Intensification of agriculture was linked with collectivisation and removing of hedges and riparian vegetation, the decrease in the mosaic of arable fields, grasslands and woods. Traditional extensive farming with individual farmer attitude to landscape was transformed to collectivisation with overall interest in land exploitation (Bezák and Petrovič 2006). Typical features of historical agricultural landscapes were destroyed around most of the country by the establishment of a new structure of agricultural plot division (large block fields).

Only in less accessible, less fertile localities, remote and marginal areas with extreme natural conditions, was the original agricultural landscape partially preserved, not losing the shape of a cultural - historical countryside. These areas represent regions with specific combinations of natural and cultural diversity, including a high visual quality of the landscape.

At the same time partial abandonment and reforestation has started as a consequence of changes in employment and decline in population.

\section{Land use changes after 1990}

After 1990 one can notice a depression of agriculture, denationalisation of agricultural land, which was connected with the restitution (returning properties to former owners and their relatives), privatization (process of selling state ownership to individual owners, often for lower than market price) and decay of subsidies systems (Bičík and Jančák 2006). It resulted in bankruptcy of many state agriculture corporations and abandonment of agricultural landscape. Due to economical limitations, the agriculture became less intensive. The decrease in using fertilizers was noticeable after 1991, but now this is slightly increasing. One of the positive effects on landscape is that the landscape was partly retrospectively diversified by virtue of land restitution. Although the decline of traditional use of farmland is noticeable in Slovakia, in some regions local inhabitants are strongly linked with traditional land use. In marginal regions, in less accessible, less fertile localities, abandonment of traditional agriculture and increased succession of the forest continues. The challenge to maintain the original agrarian landscape could be achieved by development of environmentally friendly farming with the aim to maintain natural values of the territory and by support from agro-environmental schemes. 


\section{Characteristic of selected cultural mosaics and their environment}

Four localities which are characterised by different natural conditions, agricultural and developmental trends, geo-political position, socio-economic situations and the character of the well-preserved original cultural mosaics of landscapes have been chosen (Table 1):

- The town of Svätý Jur with its viticulture tradition near Bratislava city

- The village of Liptovská Teplička with meadow-pasture potential in the Low Tatras Mts.

- The village of Osturňa in the Spišská Magura Mts. - very marginal settlements, minimum recreational potential

- The villages of Zuberec - Habovka in the National Park of The Tatras with a high recreational potential and actual non-regulated tourism.

\section{Driving forces, threats and trends in the selected agrarian settlements with mosaics}

To identify the main trends in agrarian landscape, the significant driving forces and threats, which have an impact on the agricultural mosaic have been defined. Their intensity and impact in model areas are expressed in table 2 .

The basic driving forces for mosaic in the agricultural landscape are:

- natural conditions - geological pad, relief parameters, soils, climate, slope etc.

- cultural-historical conditions of colonisation - general political and economic situation

- geopolitical setting - position of the settlements to the political boundaries of Slovakia and to the capital of Slovakia - Bratislava (considering altitude, distance and transport accessibility)

- land law - the law on land division among heirs in process of inheritance, the law about agrarian cooperatives in socialist times, etc.

- agro environmental schemes - support for individual farmers or cooperatives to cultivate the mosaic

- protection of nature, protection of cultural monuments - regulations for urbanization and land-use

- demographic structure of inhabitants - age of population - productive and post productive proportion of inhabitants; occupational structure of the population proportion of those working in agriculture and in non-agricultural domains outside or inside of the dwelling site. 


\section{Table 1: Examples of cultural mosaic landscapes in Slovakia and characteristics of selected driving forces and their present state}

\begin{tabular}{|c|c|c|c|c|}
\hline Site and natural conditions & Colonisation & Geopolitical setting & Character of collectivization & $\begin{array}{c}\text { State - specific features of mosaics and } \\
\text { landscape }\end{array}$ \\
\hline $\begin{array}{l}\text { Svätý Jur } \\
\text { - Situated on alluvial cone } \\
\text { in the Malé Karpaty Mts. } \\
\text { - faulted slopes and plains } \\
\text { - prevailingly on crystalline } \\
\text { subsoil with cambisols and } \\
\text { rankers } \\
\text { - moderately warm climatic } \\
\text { region - mean July } \\
\text { temperature over } 16^{\circ} \mathrm{C} \text {, } \\
\text { mean annual precipitation } \\
600-850 \mathrm{~mm}\end{array}$ & $\begin{array}{l}\text { - settled by the } \\
\text { Slovenians in } 9^{\text {th }}-11^{\text {th }} \\
\text { century } \\
\text { - influence of German } \\
\text { colonisation in } 13^{\text {th }} \text { and } \\
16^{\text {th }} \text { century } \\
\text { - winegrowing in the } \\
\text { Middle Ages - one of the } \\
\text { most productive } \\
\text { economic sectors with } \\
\text { highly developed } \\
\text { organisation }\end{array}$ & $\begin{array}{l}\text { - small foothill of the } \\
\text { Carpathians, flat Podunajská } \\
\text { nížina lowland } \\
\text { - altitude } 130 \text { - } 370 \mathrm{~m} \\
\text { - situated in western } \\
\text { Slovakia about } 15 \mathrm{~km} \text { from } \\
\text { the capital city of Bratislava } \\
\text { - belongs to satellite towns } \\
\text { of Bratislava }\end{array}$ & $\begin{array}{l}\text { - the institution of agricultural } \\
\text { cooperative was based in Svätý Jur in } \\
\text { the year } 1950 \\
\text { - large part of the traditional small- } \\
\text { structured vineyard landscape was } \\
\text { destroyed } \\
\text { - to intensify the vine production the } \\
\text { large block- vineyards were created } \\
\text { - the new big terraces, oriented along } \\
\text { the contour line were created on steep } \\
\text { slopes during the } 1970 \text { - } 1980 \\
\text { - creation of the new vineyard } \\
\text { terraces required enormously high } \\
\text { costs from the state financial resources }\end{array}$ & $\begin{array}{l}\text { - winegrowing tradition since the } 13^{\text {th }} \\
\text { century } \\
\text { - original strip-like, terraced vineyards, } \\
\text { oriented along the fall line, with several } \\
\text { centuries old stone hedges and } \\
\text { stonewalls } \\
\text { - preserved chestnut or oak groves, } \\
\text { brushy and herbaceous vegetation with } \\
\text { high biodiversity } \\
\text { - preserved urban structure of medieval } \\
\text { fortified town with traditional } \\
\text { bourgeois houses and the houses of the } \\
\text { vintners (Svätý Jur town became a free } \\
\text { royal town in the } 16^{\text {th }} \text { century) } \\
\text { - attractive frame of forests of the } \\
\text { Small Carpathians Mts and lowland } \\
\text { boggy forest of Jurský Š́r }\end{array}$ \\
\hline $\begin{array}{l}\text { Liptovská Teplička } \\
\text { - small basin surrounded by } \\
\text { mostly steep }\left(12^{\circ}-17^{\circ}\right) \text { or } \\
\text { moderate slopes in the Low } \\
\text { Tatras Mts. } \\
\text { - carbonate pad } \\
\text { - rendzinas, cambisols } \\
\text { - cool climatic region - } \\
\text { mean July temperature } 12 \text { - } \\
16^{\circ} \mathrm{C} \text {, mean annual } \\
\text { precipitation } 800-1100 \mathrm{~mm}\end{array}$ & $\begin{array}{l}\text { - colonised in the } 17^{\text {th }} \\
\text { century by Goral settlers } \\
\text { - colonization on } \\
\text { Walachian law } \\
\text { - period of feudal } \\
\text { discords, threat of } \\
\text { Turkish aggression, } \\
\text { cultural and economic } \\
\text { regress } \\
\text { - overpopulation by } \\
\text { emigrants from the South } \\
\text { and the effort to utilize } \\
\text { uninhabited mountain } \\
\text { areas. }\end{array}$ & $\begin{array}{l}\text { - the inner part of the Low } \\
\text { Tatras Mts. } \\
\text { - altitude } 846-1429 \mathrm{~m} \\
\text { situated in the northern } \\
\text { Slovakia about } 350 \mathrm{~km} \text { from } \\
\text { the capital city of Bratislava }\end{array}$ & $\begin{array}{l}\text { carried out in } 1975 \\
\text { reclamations } \\
\text { made in some more suitable areas for } \\
\text { arable land } \\
\text { original arable fields in mosaics were } \\
\text { grassed } \\
\text { after } 1989 \text { farmers have rented the } \\
\text { land to a cooperative which apply } \\
\text { agro environmental schemes to mow } \\
\text { grass on the cultural mosaics }\end{array}$ & $\begin{array}{l}\text { - original strip-like structure of small } \\
\text { scale arable fields and semi-natural } \\
\text { mesophilous meadows and poor } \\
\text { pastures with forms of anthropogenous } \\
\text { relief - balks (terraces, mounds and } \\
\text { heaps, etc.) } \\
\text { - still used traditional practices in } \\
\text { agriculture } \\
\text { - typical wooden architecture - } \\
\text { dwelling houses, complex of barns; } \\
\text { complex of } 350 \text { log cabin cellars } \\
\text { - attractive frame of the forested Low } \\
\text { Tatras Mts. }\end{array}$ \\
\hline
\end{tabular}




\section{Zuberec - Habovka}

- foothill of the West Tatras

- Rohace Mts.

- region situated in northern

Slovakia

- badlands on the flysch

- moderately cool climatic subregion - mean July temperature $12-16^{\circ} \mathrm{C}$, annual precipitation 800 -

\section{$1200 \mathrm{~mm}$}

\section{Osturňa}

- $9 \mathrm{~km}$ long valley with mostly steep slopes $\left(12^{\circ}\right.$ -

$\left.17^{\circ}\right)$ in the Spišská Magura Mts.

- flysch pad

- cambisols and rankers

- cool climatic region mean July temperature 12 $16^{\circ} \mathrm{C}$, mean annual precipitation $800-1100 \mathrm{~mm}$
- influence of Walachian colonisation in the $16^{\text {th }}$ century - traditional pastures landscape
- marginal position on the Polish boundary

- altitude 725 - $2178 \mathrm{~m}$

- $346 \mathrm{~km}$ from the capital city of Bratislava
- carried out in the $1970 \mathrm{~s}$

- mosaic of agricultural landscape was partially preserved in less accessible and marginal areas with extreme natural conditions

- later abandoned and threatened by succession
- colonised in the $16^{\mathrm{th}}$

century by the

Ruthenians in framework

of the scholties

colonization on

Walachian law
- marginal position on the

Polish boundary

- altitude 645 - 1295 m

- north Slovakia

- about $390 \mathrm{~km}$ from the

capital city of Bratislava
- the mostly traditional meadowpastures landscape characterised by rangy slope relief and typical architecture

- preserved mosaic of agricultural land and hedgerows in less accessible areas of the cadastre

- renewal of traditional strip like agricultural plots close to the settlement after 1990

- typical architecture of Goral wooden houses protected as the Folk architecture historical reserve

- original strip-like and small-block arable fields and semi-natural mesophilous meadows and pastures and fallows with forms of anthropogenous relief - balks (terraces, rocky mounds and heaps, etc.)

- still used traditional practices in agriculture in small areas, big proportion of fallows 
Table 2: Intensity of influence of the main driving forces and main threats in the selected settlements

\begin{tabular}{|c|c|c|c|c|c|}
\hline & & Svätý Jur & $\begin{array}{c}\text { Liptovská } \\
\text { Teplička }\end{array}$ & $\begin{array}{l}\text { Habovka- } \\
\text { Zverovka }\end{array}$ & Osturňa \\
\hline \multirow{9}{*}{$\begin{array}{l}\text { driving } \\
\text { forces }\end{array}$} & natural conditions & & & & \\
\hline & $\begin{array}{c}\text { cultural-historical } \\
\text { conditions of } \\
\text { colonisation }\end{array}$ & & & & \\
\hline & geopolitical setting & & & & \\
\hline & land law & & & & \\
\hline & $\begin{array}{c}\text { agro environmental } \\
\text { schemes }\end{array}$ & & & & \\
\hline & nature protection & & & & \\
\hline & $\begin{array}{c}\text { protection of cultural } \\
\text { monuments }\end{array}$ & & & & \\
\hline & age of the population & & & & \\
\hline & $\begin{array}{c}\text { occupational pattern of } \\
\text { inhabitants }\end{array}$ & & & & \\
\hline \multirow{3}{*}{ threats } & $\begin{array}{c}\text { non-regulated } \\
\text { urbanisation }\end{array}$ & & & & \\
\hline & $\begin{array}{c}\text { non-regulated } \\
\text { recreation } \\
\end{array}$ & & & & \\
\hline & $\begin{array}{c}\text { abandonment and } \\
\text { subsequent overgrowth }\end{array}$ & & & & \\
\hline & & $\begin{array}{l}\text { igh intensity } \\
\text { hiddle intensity } \\
\text { w intesity }\end{array}$ & & & \\
\hline
\end{tabular}


Based on identified causality, the landscape changes are related to the intensification of agriculture, extensification of agriculture, urbanisation-industrialisation, enlargement (exhaustion) of natural resources, afforestation, deforestation and other anthropogenic causes (Feranec et al. 2000). The main threats for the existence of cultural landscape mosaic in present are:

- non-regulated urbanisation - it threatens areas close to the high urbanized localities (cities, towns) which are exploding mostly for private development.

- non-regulated recreation - is connected with the construction of recreational objects (hotels, ski-lifts, etc.) which may disturb the aesthetical value of landscape in open country with mosaics or directly inbuilt areas of settlements.

- abandonment and the subsequent overgrowth of agricultural mosaic landscapes by non-forest wood vegetation - is connected with unfavourable demographic development resulting in the increase of post productive inhabitants mostly in marginal areas or the increase in new inhabitants without agricultural skills or interest in maintaining the mosaics especially near urbanized areas.

- National and international policy, unregulated market - market intervention (through agricultural policy), rural development policy, environmental policy, agricultural intensification has been driven in some cases by the Common Agricultural Policy (CAP), along with unregulated market prices there made agriculture in less favourable region noncompeting.

\section{The main trends}

Four model areas, representing different cultural landscape in different parts of Slovakia are distinguished by different developmental and disintegration trends.

\section{Svätý Jur}

Developmental trend of the mosaic - is connected with the application of territorial developmental regulation in accordance with the protection of the surrounding cultural landscape and with increase of ecological awareness of the local inhabitants what would provide a balance between a desire for dwelling comfort and demands for environmental quality. The development of agro tourism, oriented to viniculture and increasing application of the agro environmental schemes in the frame of ecological farming, grassland and nonforest wood vegetation protection, soil protection from erosion in vineyards etc., would contribute to sustainable development utilization of mosaics in the landscape of the town of Svätý Jur.

Disintegration trend of the mosaic - in Svätý Jur cadastre is mostly influenced by ongoing unfavourable demographic development and non-regulated urbanisation and recreation. Svätý Jur town will become a suburb of Bratislava, the capital of Slovakia. The local municipality will not be able to regulate the pressures of developers and their profityielding socio-economical development in the short term. The practical application of the existing landscape ecological plan and research results (Krnáčová et al. 2005) for sustainable development of the cultural landscape will be objectionable. The trend of the immigration of wealthy citizens, who prefer an individualistic and high lifestyle, will increase. As a consequence of this, the old vineyards will be replaced by new villas close to town and houses for recreation in the transition zone between the vineyards and the forest. The decrease of the cultural mosaic will affect biodiversity and ecological stability of the landscape. 


\section{Liptovská Teplička}

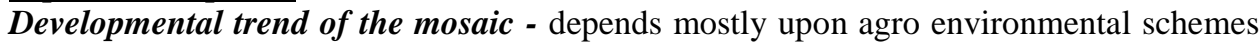
used by the agricultural cooperative that helps to maintain all narrow-strip parcels rented from owners by mowing grasslands. It also depends on sustaining a favourable demographic condition, a relatively high share of productive and preproductive inhabitants, and favourable economic conditions, job opportunities in close towns which would provide residents with primary living and supplementary possibilities to cultivate land for food crops. The development of agro tourism and skiing in a semi intensive way, the protection of still unprotected folk architecture which increases the cultural-historical potential of the territory and which are connected with agricultural land utilization are also essential for the survival of the mosaic of agricultural landscape.

Disintegration trend of the mosaic - Abandonment of grassland and overgrowth of the mosaic may be a result of not applying agricultural schemes, the disestablishment of the agricultural cooperative, the permanent migration of the younger population for jobs and population aging. On the other hand, the development of intensive recreation (new big hotel constructions, new ski lifts, etc.), and the destruction of agricultural architectural structures could cause this disintegration.

\section{Osturňa}

Developmental trend of the mosaic - One of the ways to maintain agricultural mosaics of grassland, arable fields and hedges and keep the traditional management of fields, is the application of the agro environmental scheme for mowing the grassland mosaic or cultivation of arable land on mosaics. Because there is no agricultural cooperative, the agro environmental scheme should be used by local farmers or neighbouring agricultural associations. Recreational potential of the area is very low; the presumption for development of agro tourism is the presence of a Folk architecture historical reserve in Osturňa village.

Disintegration trend of the mosaic - Cool climate and unfavourable natural conditions for agriculture poses risk for maintenance of agricultural mosaic. The progressive aging of inhabitants and the development of just weekend house tourism without management of agricultural land would lead to fast overgrowth of agricultural mosaic by woody vegetation and disintegration of the attractive landscape view.

\section{Zuberec - Habovka}

Developmental trend of the mosaic - After 1990, due to economical limitations, most of the large-block fields were retransformed to pastures and meadows. One of the positive consequences is that the landscape was partly retrospectively diversified by the virtue of land restitution, resulting in a partial renewal of traditional agriculture and original plot division close to the village. Some remote and marginal cultural mosaics have been preserved since the collectivisation period. Although the decline of the traditional use of farmland is noticeable in Slovakia, local inhabitants are strongly linked with traditional land use, especially middle-age and older people. Young people are not so interested in traditional farming and they are looking for new possibilities of income. The challenge to maintain the original agricultural mosaic landscape could be the support and application of an agro-environmental scheme. Due to the attractive sub mountain cultural agrarian landscape and the neighbourhood of the National Park of The Tatras, tourism development has become significant in the last 15 years. Challenge for maintenance of traditional agricultural landscape may be the development of agro tourism. 
Disintegration trend of the mosaic - Decline of agriculture is noticeable after 1990, mostly in the regions with severe natural conditions unsuitable for intensive agriculture which were supported by state subsidies during the period of agriculture intensification. Agricultural land was changed to grassland or is abandoned. Tourism development is connected with the expansion of building accommodation facilities, but new buildings are not always linked with traditional architecture. The demand for new hotels and the increasing number of tourists put pressure on the protected areas and natural habitats. The new possibility of economic income from tourism has also impact on the employment pattern; namely it has caused a decrease of employees in agriculture. Remote and marginal cultural mosaics, preserved in the collectivisation period, face abandoned and are threatened by succession and reforestation.

The example of the model areas in Slovakia has shown that the results of land use development and the co-operation of driving forces can be different and unique in every region and country. The different trends could be common also for other regions in Slovakia.

\section{DISCUSSION}

Declining landscape diversity and biological diversity, related to the intensification of agricultural and silvicultural practices, land abandonment and other land uses are significant issues of cultural landscapes (Young at al. 2005). Although a large area of agricultural landscape in Slovakia was transformed to grassland after 1990, the area of traditionally extensively utilized semi-natural grassland is declining throughout Europe. The study of present trends and threats has shown high risk of decline or even irreversible loss of biodiversity linked to specific biotopes of historical agricultural landscape in the near future, due to abandonment and subsequent forest succession or urban pressure. Several studies have been undertaken, to evaluate land-use impact on plant communities in grasslands (Cousins et al. 2003; Lindborg and Eriksson 2005; Maciejowski 2001; Špulerová 2008b). The early successional stages are positively marked by increase of local biodiversity and landscape aesthetic value (Kozak et al. 1999), subsequently most of the abandoned grassland are threaten by succession. Research results of land use changes in the Carpathians clearly resemble forest transition processes (Mather 1992) which have been taking place for at least 150 years in the entire mountain area of Europe due to extensive land abandonment (MacDonald et al. 2000; Piussi 2000). Marginalization of agricultural land leads to secondary afforestation (Václavík and Rogan 2009). Forest expansion in Europe has contributed to the major landscape change, perceived as a loss of cultural landscapes and a threat to biodiversity (Hunziker 1995; Weiss 2004). Forests are now expanding in the less fertile regions, mainly in the mountainous frontier (Augustyn 2004). The intensity of arable-land exploitation in more fertile lowland regions is increasing, but its area is still decreasing (Bičík et al. 2001).

Agricultural landscape represents almost half of the territory of Slovakia and plays an important role in production as well as from the ecological point of view. Production of agricultural commodities is inseparably jointed with production of non-productive functions that are considered as positive externalities or public goods. The functional market for the majority of public goods does not exist and therefore their market price is unknown and non-reflected (Brodová 2007). The whole society profits from maintenance of nonproductive functions provided by agriculture such as natural hazard prevention, protection, management and development of the rural landscape, which is deeply adherent to food 
quality and food safety. An important fact from the ecological point of view is that a significant part of biodiversity in Slovakia is a part of agricultural landscape. The main sources of local biodiversity represent primary or semi-natural meadows and pastures, abandoned grass-grown former arable fields, small wetlands and hedges, as well as a mosaic of small-scale arable fields and permanent agricultural cultivations, which are linked to balks and margins of cross fields tracks. They are of irreplaceable ecological, cultural and historical value.

The question is: how to maintain the historical agricultural landscape and how to stop the decrease of the cultural mosaic?

The following steps and activities should be undertaken or improved:

- the active involvement of community life within the sustainable development and the rise of ecological awareness and education

- respecting the necessity of the preservation of primary agricultural landscapes in territorial planning documentation

- renewing the old traditions, agricultural technologies and old forms of agricultural land utilisation in relationship with tourism development

- regional and agro-environmental policies which will support maintenance of cultural landscape.

Development of rural area is also depended upon natural conditions and other various assumptions. As obvious on examples of our study areas, villages Zuberec and Osturňa are characterized by roughly identical natural conditions, but their development trends are significantly divergent, as tourism development in Zuberes is conditioned by the presence of mountains and the national park.

Several policies preventing marginalisation and land abandonment in mountain rural areas (European Environment Agency 2004; European Landscape convention 2000) may slow down, or even stop the forest expansion. At least for mountainous regions it is very likely that without the introduction of EC-compatible state subsidies - such as direct payments - large parts of the cultivated land might be abandoned and subject to spontaneous reforestation. Conservation and management of agrarian landscape have to result in outcomes of landscape ecological planning, which prepares the bases for optimum organization and creates the unavoidable database on landscape for different spatial planning procedures.

\section{ACKNOWLEDGEMENT}

This work was supported by the Slovak Research and Development Agency under the contract No. LPP-0135-06.

\section{REFERENCES}

Antrop, M. (2005). Why landscapes of the past are important for the future? Landscape and Urban Planning 70: 21-34.

Augustyn, M. (2004). Anthropogenic Pressure in the Environmental Parameters of the Bieszczady Mountains. Biosphere Conservation, 6: 43-53.

Bičík, I., Jeleček, L. \& Štepánek, V. (2001). Land-use changes and their social driving forces in Czechia in the 19th and 20th centuries. Land Use Policy, 18 (1): 65-73. 
Bičík, I., Jančák, V. (2006). Czech agriculture in the integrating Europe. Acta Geographica Universitatis Comenianae, 48: 155-165,

Birks, H., Birks, H. J. B., Kaland, P. E. \& Moe, D. (2004). The Cultural Landscape - Past, Present and Future. Cambridge University Press, 593 pp.

Bezák, P., Petrovič, F. (2006). Agriculture, Landscape, Biodiversity: Scenarios and stakeholer perceptions in the Poloniny National park (NE Slovakia). Ekológia (Bratislava), 25 (1): 82-93.

Brodová, M. (2007). Úloha nevýrobných funkcií polnohospodárstva v udržatel'nom rozvoji vidieka aich kvantifikácia. Výskumný ústav ekonomiky pol'nohospodárstva a potravinárstva, Bratislava, $40 \mathrm{pp}$.

Bruun, H.H. (2000). Patterns of species richness in dry grassland patches in an agricultural landscape, Ecography 23: 641-650.

Cousins, S.A.O., Eriksson O. (2001). Plant species occurrences in a rural hemiboreal landscape: effects of remnant habitats, site history, topography and soil, Ecography 24: 461-469.

Cousins, S.A.O., Lavorel, S. \& Davies, I. (2003). Modelling the effects of landscape pattern and grazing regimes on the persistence of plant species with high conservation value in grasslands in south-eastern Sweden. Landscape Ecology, 18: 315-332.

Dobrovodská, M. (1998). Development of the relationship between man and landscape in mountain agricultural landscape. In: Miklós, L. (Ed.): Evaluation and perception of Landscape patterns. pp. 101-106. Banská Štiavnica,

Dobrovodská, M. (2003). Vývoj vzt’ahov medzi krajinou a človekom na modelovách územiach v katastroch obcí Liptovská Teplička, Osturňa a malá Franková. Dissertation, Institute of Landscape Ecology SAS, Bratislava, $141 \mathrm{pp}$.

Dobrovodská, M., Štefunková, D. (1996). Historical agricultural forms of anthropogenous relief in arable-meadow-pasture landscape and vineyard landscape. Acta Environmentalica UC (Bratislava), 7: 85 - 91

Global International Waters Assessment (GIWA) (2001). DPSIR framework for State of Environment Reporting. European Environment Agency (EEA). Copenhagen. Retrieved June 2009, from http://www.unep.org/dewa/assessments/ecosystems/water/ vitalwater/12. htm\#13

European Environment Agency (2004). Agriculture and the environment in the EU accession countries. Copenhagen, Environmental issue report 37 European Landscape convention, 2000, Florence. Retrieved June 2009, from http://conventions.coe.int/Treaty/ en/Treaties/ Html/176.htm

Feranec, J., Šúri, M., Ot'ahel', J., Cebecauer, T., Kolář, J., Soukup, T., Zdeňková, D., Waszmuth, J., Vâjdea, V., Vîjdea, A.M. \& Nitica C. (2000). Inventory of major landscape changes in the Czech Republic, Hungary, Romania and Slovak Republic 1970s - 1990s. International Journal of Applied Earth Observation and Geoinformation. 2 (2): 129-139.

Huba, M. (1988). Historické krajinné štruktúry. Ochranca prírody, odborná príloha spravodajca MV SZOPK Bratislava, 62 pp.

Hunziker, M. (1995). The spontaneous reforestation in abandoned agricultural lands: perception and aesthetic assessment by locals and tourists. Landscape Urban Planning, 31: 399-410. 
Krnáčová, Z, Štefunková, D., Dobrovodská, M., Hrnčiarová, T., Pavličková, K., Pauditšová, E., Potočková, L., Košovič, P., Kubíček, F., Janotka, V. \& Gajdoš, V. (2005). Integrovaný rozvoj turizmu v mikroregióne Svätý Jur (Integrated development of tourism in Svätý Jur microregion). Bratislava: Institute of Landscape Ecology of SAS, 199 pp.

Mac Donald, D., Crabtree, J.R., Wiesinger, G., Dax, T., Stamou, N., Fleury, P., Lazpita, J.G. \& Gibon, A. (2000): Agricultural abandonment in mountain areas of Europe: environmental consequences and policy response. Journal of Environmental Management, 59: 47-69.

Kozak, J., Troll, M. \& Widacki, W. (1999). Semi-natural landscapes of the Western Beskidy Mts. Ekologia, Bratislava, 18/1: 53-62.

Lindborg, R., Eriksson, O. (2004). Historical landscape connectivity affects present plant species diversity. Ecology 85:1840-1845.

Lindborg, R., Eriksson, O. (2005). Functional response to land use change in grasslands: Comparing species and trait data. Ecoscience, 12 (2): 183-191.

Lipsky, Z. (1995). The changing face of the Czech rural landscape. Landscape and Urban Planning 3/1-3: 39-45

Mather, A.S. (1992). The forest transition. Area 24/4: 367-379.

Maciejowski, W. (2001). Changes of natural landscape in the Beskid Niski Mountais during 1938-1998 as exemplified by the Ropianka stream catchment. Ekologia, Bratislava, 20, Suppl. 3: 100-109.

Piussi, P. (2000). Expansion of European mountain forests. In: Price, M.F., Butt, N. (Eds): Forests in sustainable mountain development: a state of knowledge report for 2000. pp. 1925. IUFRO Research Series 5, CABI Publishing, Wallingford-New York.

Ružička, M., Miklós, L. (1982). Landscape ecological planning (LANDEP) in territorial planning. Ekológia (ČSSR), 1: 297-312.

Špulerová, J. (2008a). Land use changes in the Veselovianka river catchment in the Horná Orava region. Ekológia (Bratislava), 27/3: 326-337.

Špulerová, J. (2008b). Succession changes in extensively used agricultural land. Ekológia (Bratislava). 27/1: 54-64.

Štefunková, D., Dobrovodská, M. (1997). Historické pol’nohospodárske formy využitia zeme - ich úloha v trvalo udržatel'nom rozvoji (Historical agricultural forms of land use significance in sustainable development). Acta Environmentalica Universitatis Comenianae Bratislava, 7: 149-153.

Václavík, T., Rogan, J. (2009). Identifying Trends in Land Use/Land Cover Changes in the Context of Post-Socialist Transformation in Central Europe: A Case Study of the Greater Olomouc Region, Czech Republic. GIScience \& Remote Sensing, 46, No. 1: 54-76.

Weiss, G. (2004). The political practice of mountain forest restoration-comparing restoration concepts in four European countries. Forest Ecology and Management, 195/1-2: 1-13.

Young, J., Watt, A., Nowicki, P., Alard, D., Clitherow, J., Henle, K., Johnson, R., Laczko, E., McCracken, D. \& Matouch, S. (2005). Towards sustainable land use: identifying and managing the conflicts between human activities and biodiversity conservation in Europe. Biodiversity and Conservation 14/7: 1641-1661. 